\title{
ARTIG0S
}

\section{ANCHIETA E O IV CENTENÁRIO DE PINHEIROS.}

No Regimento de Tomé de Souza, assinado em Almeirim a 17 de dezembro de 1548, primeira "constituição" com que se regeu o nosso país, declarava Dom João III:

"A principal causa que me moveu a mandar povoar as ditas terras do Brasil, foi para que a gente dela se convertesse à nossa fé católica" (1).

Era exatamente aquêle "melhọr fruto" que, na embevecida carta de Pero Vaz de Caminha, se deveria plantar na nova terra, descoberta pela frota cabralina, no roteiro das fndias Orientais.

Uma série de disposições visam, nesse Regimento, à consecução de tão elevado objetivo. Uma delas assim reza:

"Porque parece que será grande inconveniente os Gentios, que se tornaram cristãos, morarem na povoação dos outros e andarem misturados com êles, e que será muito serviço de Deus e meu apartarem-se de sua conversação, vos encomendo e mando que trabalheis muito por dar ordem como os que forem cristãos morem juntos, perto das povoações das ditas Capitanias, para que conversem com os cristãos e não com os gentios e possam ser doutrinados e ensinados nas coisas de nossa santa fé" (2).

Estava aí claramente delineado o sistema dos aldeiamentos de índios cristãos e catecúmenos que, por tôda a parte, procuraram organizar os jesuítas, para a catequese dos aborígenes, já que com êsse escopo primordial haviam sido, com Tomé de Souza, enviados ao Brasil. Nóbrega e seus companheiros iam ser, na estruturação da nova sociedade euro-americana, que formou o substratum do povo brasileiro, os instrumentos providenciais, de que se valeu o Estado português,

\footnotetext{
(1). - História da colonizaçāo portuguêsa do Brasil (HCPB), Pôrto, 1924, III, (2). - HCPs, III, 350 .
} 
nc. desempênho de seus compromissos com a Igreja Católica (3).

A idéia do superior da missão jesuítica no Brasil, de fundar uma cidade cem léguas para o interior, entre os índios carijós, não se enquadrava nas cláusulas dêsse Regimento. Projeto, diríamos hoje, "anti-constitucional"! Vetou-o, por issu mesmo, o primeiro governador geral. Para a fundação de São Paulo, a proximidade de Santo André da Borda do Campo foi assim uma condição indispensável. Na aldeia de Piratininga, entretanto, haviam fundado os jesuítas, por Nóbrega para aqui mandados, alguma coisa mais que a aldeia cristã dè São Paulo.

O que se fundou aqui, a 25 de janeiro de 1554, foi o primeiro Colégio da Companhia no Brasil, tendo por mestre durante um decênio ao jovem José de Anchieta. Tal circunstância permitiu que o precário aldeiamento formado pelos tupis do Campo em 1553, sujeito à inconstância do nomadismo indígena, evoluisse para a condição de uma nova povoação portuguêsa, que em 1560 absorveu a Vila de Santo André. Material e espiritualmente falando, aliás, bem escassas eram, no mesquinho arraial da Borda do Campo, os sintomas de sobrevivência .

Os índios de Tibiriçá, de Caiubí, de Tamandiba, ou outro morubixaba que fôsse, concentrados a conselho dos Padres na colina de Inhapuambuçú, e ali visitados por Nóbrega, em fins dor agôsto de 1553, eram apenas os que se dispunham a abraçar c cristianismo, a isso impelidos desde 1550 pelas exortações df Leonardo Nunes. Muitos outros haviam permanecido arranchados em suas tabas nativas, doze ao todo, no dizer de Arschieta, naqueles primeiros anos, a uma, duas e três léguas d. Piratininga, por água e por terra (4).

Uma dessas tabas, visitada em 1550 pelo Abarébebê, como apelidavam os tupis do Campo ao andejo primeiro apóstolo de São Vicente, devia estar localizada nesse ponto de convergência, que foi o antigo váu do rio Jurupatuba, ou dos Pi-

(3). - R. Ricard, Les Jésultes an Brésil pendat la seconde moitié du XVIe. siècle, Revue d'histoire des missions, XIV, n. 4 (déc., 1937), 469. Galanti, I, 162. "El-Rei Dom Sebastiáo, pela obrigaçáo que tem a Coróa de Portugal a conversáo dos naturats desta terra, per razáo dos dízimos, fun dou três coléglos, em que houvesse ministros que se ocupassem nela". explicam em 1592 os jesuitas do Brasil, respondendo aos Capitulos de" Gabriel Soares, Anais da Bibl. Nac., LXII, 363-364.

(4). - Anchieta, Informaçáo do Brasil, Cartas Jes., III, 321. 
nheiros. A existência ali de um bosque de araucárias, com a oferta de seus frutos alimentícios, o rio com suas pescarias, a antiga trilha dos tupis, que dos Campos de Piratininga ia em busca de Araritaguaba no rio Tietê, donde havia comunicação fluvial com o Paraguai (5), tudo isso nos convence de que êsse ponto era uma das querências primitivas dos nômades do Planalto.

Nem é provável que se despovoasse inteiramente, com a concentração dos catecúmenos na nova aldeia de Piratininga, anteriormente à visita de Nóbrega. Com a debandada entre 1556 e 1557, depois de inaugurada a 1 de novembro de 1556 da nova igreja de taipa em São Paulo, da maioria dos piratininganos, que se distribuiram, nos informa Anchieta, em três aldeias, o mesmo acontecendo então com os índios de Jaraibatiba, repovou-se ou cresceu em número de habitantes a velha Aldeia dos Pinheiros, que dai por diante começou a receber mais amiúde a visita de Anchieta e seus companheiros (6).

Nas suas cartas de 1556 e 1557 , menciona êle mais de uma vez êsse trabalho catequético:

\begin{abstract}
"Guarda-se a mesma ordem de doutrina que antes, aqui (em Piratininga) e em Jeraibatiba, e peculiar cuidado acêrca da instituição dos meninos, dos quais alguns perseveram, outros se mudam com seus pais a outras moradas... Assim que insistimos com contínuos sermões, aqui e em outros lugares em derredor" (7).
\end{abstract}

Em São Paulo e nas aldeias vizinhas, no decurso do ano dr 1556, se introduzira um método recém-elaborado na língua tupí, para essa doutrinação (8).

Trata-se dos Diálogos da Fé, compostos por Anchieta na língua da terra, entre 1555 e 1556, logo após terminada a elaboração da Arte da gramática da língua mais usada na costa do Brasil. No seu zêlo da salvação das almas dos brasis, não perdia tempo o jovem José de Anchieta. De palavra e por escrito, empenhou-se totalmente na magna emprêsa da conversão dos infiéis do Novo Mundo (9). Ia juntando assim os legítimos títulos, que lhe mereceram da autoridade eclesiástica, por

(5). - T. Sampaio, São Paulo de. Piratininga no fím do século XVI, Rev. do Inst. Hist. e Geogr. de São Paulo (RIHGSP), IV, 262.

(6). - Grã, Carta de Piratininga, a 7 de abril de 1557, Novas C. Jes., 182-183.

(7). - Anchieta, Carta de fim de abril de 1557, Mon. Bras., II, 365.

(8). - Vasconcelos, Crônica, 1. III, n. 12, citando (1a. ed.) os Apontamentos do Padre José (de Anchieta).

(9). - H. A. Viotti, S. J., Anchieta e a Eucaristia, Verbum, XII (1955), 313. 
ocasião de suas exéquias, o epíteto inteiramente justo de Apóstolo do Brasil.

Dos aborígenes egressos de Piratininga é possível que alguns, no seu congênito nomadismo, tivessem regressado a São. Paulo. Referindo-se à situação de Piratininga, durante o ano d€ 1559 e princípios do seguinte, antes da mudança dos moradores de Santo André para junto do Colégio de São Paulo, por ordem de Mem de Sá, escreve o canarino:

"Procedem os índios na doutrina da fé e, em lugar dos catecúmenos, que de Piratininga se foram (entre 1556 e 1557), vieram outros de diversos lugares, que sevieram unir segundo a vida cristã, fizeram casa de taipa para sempre morarem, para os quais deu grande ajuda o Padre Afonso Brás, com incansável trabalho" (10).

O ano de 1560 se apresenta como um marco miliário na história da Aldeia dos Pinheiros. A êsse respeito cita Frei Gaspar di Madre de Deus à fôlha 178 verso do Livro II do Registra das Sesmarias, que principia em 1562, n. ${ }^{\circ} 1$ do Cartório da Provedoria da Fazenda Real de São Paulo, consultado ainda no século passado por Azevedo Marques, documento que infelizmente já não é encontradiço no Arquivo do Estado, onde se dfveria encontrar se existisse.

Nesse ano, assegura o historiador beneditino, nas suas Memórias para a história da Capitania de São Vicente, executando-se a ordem de Mem de Sá, pela qual

$$
\text { "mandou extinguir a Vila de Santo André", }
$$

transferindo-se os seus habitantes para São Paulo de Piratininga,

"vendo (os índios ali moradores) que iam concorrendo portuguêses e ocupando as suas terras, desampararam São Paulo e foram situar-se em duas aldeias, que novamente edificaram, uma com o título de Nossa Senhora dos Pinheiros e outra com a invocação de São Miguel" (11).

Por sua vez, na Memória sôbre as aldehas de índios da $\mathbf{C a}$ pitania de São Paulo, reproduz José Arouche de Toledo Rendon, quase ao pé da letra, o trecho de Frei Gaspar. (12). E o Briga-

(10). - Anchieta, Carta de São Vicente, a 1 de junho de 1560, Cartas Jes., III, 149-150.

11). - Op. cit., 3a. ed., (São Paulo, 1920), 233.

(12). - Op. cit., em Rev. do Inst. Hist. e Geogr. Bras. (RIHGB), IV, 296. 
deiro J. J. Machado de Oliveira, na Notícia raciocinada sôbre as: aldeias de indios da Província de São Paulo, abebera-se igual-. mente nessa fonte, para admitir o seguinte:

"sabe-se por tradição que a Aldeia dos Pinheiros, a primeira na série das que pertenceram ao círculo da $\mathrm{Ca}-$ pital, e cuja localidade era anteriormente conhecida com o nome de Carapicuiba, fundara-se naquela ano" (13).

Mas ainda noutro dos seus escritos, a Notícia dos anos em que se descobriu o Brasil, ensina-nos o erudito monge de SãoBento essa mesma origem das aldeias:

"Depois de se criar vila em São Paulo, todos êsses indios, a quem os portuguêses antigos chamaram parceiros e compadres, foram habitar nas Aldeias de Pinheiros e São Miguel, povoados nelas, senhores e naturais de Piratininga" (14).

Sôbre São Miguel, convém notar que o sítio primitivo on-. de se localizou essa aldeia não coincide com o atual, para. onde se trasladou entre 1620 e 1624 , mas com o de outro lugar, bem mais próximo de São Paulo (15) .

Tanto Pinheiros ou Jurupatuba, como São Miguel ou Ururaí, eram lugares anteriormente conhecidos e habitados pelos índios tupis do Campo. Muito de propósito omitimos o apelativo de "guaianazes", equívoco em que incidiu e enredou até hoje a muita gente o mesmo Frei Gaspar. Para tal êrro há. muito chamou a atenção dos historiadores Mestre Capistrano" de Abreu.

"A teoria de que os indios guaianases eram tupis está hoje muito abalada, dando-se como tapuias", - es-

escreve em nota aos Documentos Interessantes Antônio de. Toledo Piza.

“Tibiriçá era tupi e podia ser guianaz" (16).

A advertência é de 1915, mas a lei da inércia tem muita fốrça!

(13). - Op. cit., em RIHGB, VIII, 211. Cf. 222.

(14). - Op. cit., em Memórias para a história da capitania de săo Vicente, 3a.. ed., (São Paulo, 1920), 369.

(15). - A atual igreja ostenta no frontispicio a data de 1622. Azevedo Marques, Apontamentos da Província de São Paulo, 2a: ed., I, 357: Certidão assinada pelo Padre Francisco de Morais, a 25 de junho de 1674.

(16). - Op. cit., XIIV (1915), 81-82, nota 1. Quanto a Capistrano, v. Prefácio ao Diário da navegação de Pero Lopes de Souza, puhl. de Eugênio de Castro, 1940, e Prolegómenos ao Livr. I da História do Brasil de Fredi Vicente do Salvador, 9. 
Não houve, portanto, a nosso ver, uma fundação de aldeias novas pròpriamente falando, nesse ano de 1560 . $O$ que hcuve foi um refôrço de povoamento, com a imigração dos ír dios cristãos e catecúmenos, e a conseqüente aquisição de um predicamento novo para essas aldeias, que passaram, nessa oportunidade, à condição de aldeiamentos cristãos ou aldeias du padroado real. Tal condição não se realizou, aliás de um sí jato, como veremos, mas se foi aperfeiçoando até o ano de 1585, ano em que, em companhia do provincial José de Anchieta, as inspecionou o visitador Cristóvão de Gouveia. A data não deixa de ter, pois, um aspecto simbólico.

*

A sobredita condição de aldeiamentos cristãos supunha se$\mathrm{r}(\mathrm{m}$ desde então as antigas tabas habitadas por índios em maioria batizados, mas para que se verificasse plenamente, exigiasi- ainda o complemento dos padroeiros e das capelas, da residência para os missionários, volantes ou estáveis, e sesmarias legalizadas. Tôda esta série de atos complementares é que não se pode dissociar da atuação de Anchieta. Assim sendo, não cclhe absolutamente o argumento, quiçá algo simplista, de que não se pode atribuir a Anchieta a fundação de Pinheiros e de São Miguel, como pede a tradição paulistana, por não ser aindঊ naquele tempo sacerdote o grande apóstolo de São Paulo (17).

Ninguém mais vinculado à catequese dos indígenas da $\mathrm{Ca}$ pitania de São Vicente do que o Venerável Padre José de Anchieta, único entre os fundadores de São Paụlo, que daqui não as redou pé até êsse ano de 1560 e, com intervalos em São Vicente, aqui residiu e trabalhou até 1564 . À sua capitania predileta esteve ligado até pouco antes da morte, como se vai ver. Seu zêlo pela conversão dos brasis é posto em grande relêvo pelos seus primeiros biógrafos, Quirício Caxa (1598) e Pero Rodrigues (1605). Zêlo a que se deve a composição da Arte da Gramátíca, do Vocabulário inicial, do Catecismo e de outros tı ês opúsculos de Instrução, para uso dos catequistas, na língua geral (18).

Catequista e enfermeiro, intérprete dos sacerdotes que não sábiam a língua indígena (19), como é o caso de Manuel da Nóbrega, por exemplo, consultor e companheiro inseparável dêste

\footnotetext{
(17). - Sérgio Buarque de Holanda, Capelas antigas de são Paulo, em Rev. do SPHAN, V (1941), 105; S. Leite, I, 306.

(18). - H. A. Viotti, S. J., Anchieta e a Eucaristia, Verbum, VII (1955), 313.

(19). - H. A. Viotti, S. J., A causa de beatificação do Venerável Padre José de Anchieta, Rio, 1953, 4-5.
} 
último entre 1560 e 1564 principalmente, antigo mestre dos corumins da escola de Piratininga, antes e depois de Antônio Rodrigues, que parece tê-lo sido apenas dois ou três meses (20), em n $\in$ nhum momento esteve Anchieta alheio às atividades da emprêsa missionária dos jesuítas na Capitania de São Vicente. A êle pessoalmente, e a mais alguém, é que, na sua visita a Piratininga, já no segundo semestre de 1560 , encarrega Nóbrega de.

\section{"visitar as povoações dos índios, nossos antigos dis- cípulos" (21).}

Quando, em meados do século XVIII, redige o Padre Manuel da Fonseca, da Companhia de Jesus, no Colégio de São Paulo, a sua Vida do Venerável Padre Belchior de Pontes e, a propósito da Aldeia de Pinheiros, nela expressamente consigna tratar-se de uma

\footnotetext{
"residência criada pelo Venerável Padre José de Anchieta" (22),
}

nada mais está fazendo do que recolher para a história a autêntica tradição paulistana, conservada entre os jesuítas aqui residentes e no seio da população agrupada em tôrno do famosc colégio, que foi o germe da cidade.

Mas já antes dêle, em princípios dêsse mesmo século, recolhera Frei Agostinho de Santa Maria, no seu Santuário Mariano, tomo $\mathrm{X}$, livro III, título VI, essa mesmíssima tradição:

"Esta (Igreja, onde se venera... "a milágrosa imagem de Nossa Senhora dos Pinheiros") erigiu, levantou e dedicou à Máe de Deus o seu devoto servo, o Padre José de Anchieta, pelos anos de 1554, quando foi em missão ao sertão de São Paulo" (23).

(20). - J. A. César Salgado, José de Anchieta, o primeiro mestre-escola em Săo Paulo, Rev. de História XI (1960), n. 41, 147-161. Na fundação de Maniçoba, setembro de 1953, tomam parte Pero Correia e Antônio Rodrigues, "línguas". Um dêsses "línguas" lá ficaria como catequista. Não foi Correia, presente a 25 de janeiro, na fundação de Sāo Paulo. Logo foi Antônio Rodrigues, cujo nome por isso nāo é citado entre os fundadores de São Paulo. Em Maniçoba o substitui, meses depois, Vicente Rođrigues, com Gregório Serrão, que estavam antes em Piratininga. Nenhum documento existe, que ateste a presença de Antonio Rodrigues aqui, antes de junho de 1554. Em agôsto, mestre dos corumins é Anchieta. Informa Polanco (Chronicon, IV, 627, n. 1343) que o companheiro principal de Nóbrega, na malograda viagem de 1554 ao Perú (quem, senão Antônio Rodrigues?) adoecera gravemente. Rodrigues teria sido aqui. mestre-escola, entre maio e agôsto, quando multo.

(21). - Anchieta, Carta de 30 de agôsto de 1561, Mon. Bras., III, 370

(22). - Op. cit., 2a. ed. (São Paulo, 1932), 5.

(23). - Op. cit., loc. cit., 159; cf. Igualmente 160 . 
A data, evidentemente, só se aplica ao início do apostoladc. anchietano nos campos de Piratininga...

Se nos conformarmos com os documentos existentes, a primeira invocação religiosa da Aldeia cristã dos Pinheiros foi a de Nossa Senhora da Conceição. E' o que, explìcitamente, afirma o Padre Fernão Cardim, seja na Informação para Nosso Pa-: dre (24), seja em a Narrativa Epistolar (25) . Cremos que, sòmẹte com a fundação da Aldeia de Nossa Senhora da Conceição de Guarulhos, por volta do ano de 1587, pelo Padre Manuel Viegas, a quem Anchieta não regateou jamais os maiores estímulos para êsse trabalho (26), é que se mudou o orago de Pinheiros para Nossa Senhora do Rosário, para modificar-se mais uma vez no século seguinte, como Nossa Senhora de Monserrate. Para esta última mudança, deve ter influído a presença em São Paulo do governador Dom Francisco de Souza.

Nossa Senhora da Conceição... dos Pinheiros! São Miguel... de Ururaí! Desde a mais tenra infância em Tenerife, aprendera José de Anchieta a repetir com carinho estas duas invocações. Em São Cristóvão da Laguna, o mais velho templo, ainda hoje existente, está consagrado ao mistério da Conceição Imaculada de Maria. E a ermida de São Miguel continua atualmente de pé, na praça "del Adelantado", a dois passos de sua casa natal (27). Que algum superior maior as tenha aprovado, não tolhe que essas denominações cristãs e a escolha de tais oragos, como quer Frei Santa Maria, seja iniciativa pessoal de Anchieta.

Se alguns dêsses índios cristãos ou catequizados tomou parte (como parece averiguado para os de Ururaí, bastando lembrar o nome de Jaguanharó, mencionado por Vasconcelos) no temeroso assalto contra a Vila de São Paulo em 1562, -. quanto aos neófitos da Aldeia de Pinheiros parece ao con-

\footnotetext{
(24). - Cartas Jes., III, 450.

(25). - Op. cit., em Tratados da terra e gente do Brasil, Rio, 1925, 355.

(26). - No Santuário Mariano, $X, 160$, atribuindo a Anchieta a fundação das aldeias de São Paulo, aponta Frei Agostinho de Santa Maria êstes quatro nomes: São Miguel; Nossa Senhora da Conceição (Guarulhos), Nossa Senhora dos Pinheiros e Nossa Senhora de Marueri (Maruim, por êrro). No Roteiro do Brasil, ou Tratado Descritivo RIHGB, XIV, 95, de 1587, diz Gabriel Soares: "derredor dela (isto é da Vila de São Paulo) quatro ou cinco léguas estão quatro aldeias de índios forros cristãos, que os padres doutrinam". A última carta de Anchieta, inédita, é a que dirige em 1596 ao "Aṕstolo dos Maromomís".

(27) . - J. Rodrigues Moure, Guia Histórica de La Laguna, Tenerife, 1935, 81-117 e 175-177.
} 
trário que se mantiveram fiéis e, atendendo ao apêlo do bravo Martim Afonso Tibiriçá, confluiram a Piratiningá, que ajudaram a defender, nesse primeiro 9 de julho da história de São Paulo.

Mas já, sôbre os índios das aldeias cristãs da Capitania, pôde em 1565 traçar Leonardo do Vale estas elogiosas referências:

"A maior parte dos índios, que a armada de Estácio de Sá levou consigo a povoar o Rio, são nossos discípulos de Piratininga, os quais tanto conhecimento têm do amor, com que a Companhia os trata e trabalha por sua salvação que, com terem bem que fazer em defender suas casas e sabendo que se apregoava grande guerra contra êles, sofreram deixar suas mulheres e filhos e repartirem-se por favorecer a armada, que sem êles mui mal podia povoar. E lá andam seis meses, sofrendo mui grandes trabalhos de dia e de noite, pelo amor de nós, pelo que devem ser mui ajudados espiritualmente de todos" (28).

Anchieta e Gonçalo de Oliveira, mestre e discípulo, êste já sacerdote e só por isso superior, acompanham como capelão a expedição vicentina de refôrço à esquadra de Estácio de Sá. Quanto terá valido para a mobilização dêsses elementos a influência de Anchieta sôbre os índios e os mamelucos podemos conjeturá-lo com muito fundamento. Mas já não necessitamos de nenhuma conjetura, para afirmar que a êle principalmente ficou devendo o nosso país a dedicação e habilidade, com que, durante três penosíssimos meses, janeiro, fcvereiro e março de 1565 - e disso dará testemunho em 1619 Gonçalo de Oliveira (29) - soube manter inabalável o espírito combativo dos expedicionários, sem os quais, frisemô-lo mais uma vez, dificilmente se fundaria então o Rio de Janeiro.

Pinheiros e São Miguel, aldeias de índios cristãos do padroado real, cumpriam sua missão política, no alicerçamento du nova pátria que surgia. Aos Oficiais da Câmara de São Paulo recordará, um século mais tarde, o governador geral Afonso Furtado de Castro do Rio de Mendonça, em carta da Bahia a 7 de outubro de 1671, o papel histórico reservado pela Metrópole a tais aldeiamentos: dos índios das aldeias de ElRei, só o governador geral pode dispor com plena jurisdição,

\footnotetext{
28). - Cartas Jes., II, 450.

(29). - Arquivo Secreto Vaticano (ASV), Congr. Rit., n. 303, Processo Inf. de Olinda, fls. 304v-305v.
} 
pois a razão de ser de sua existência (na ordem temporal, se entende) é

"para Sua Alteza os ter assim prontos a seu real serviço, que é o fim delas se perpetuarem" (30).

A ausência de Anchieta, na Capitania de São Vicente, durou essa primeira vez pouco mais de dois anos. Anos em que, no estudo da teologia e no exercício da vida ascética, intensificou na Bahia sua preparação para o sacerdócio. Em princípio de 1567, presta serviços na conquista difinitiva da Guanabara e assiste à morte de Estácio de Sá, o jovem herói, cujo melhor elogio brotou de sua pena de historiador e literato. E ei-lo de volta ao "teatro de suas maravilhas". Durante novo decênio, de 1567 a 1577 , vai ser aqui o superior dos jesuítas da Capitania. Nada se realizaria aqui, nesse período, se não por sua iniciativa, ou, quando menos, com sua anuência e parecer.

Reside desta vez em São Vicente, mas sobe muitas vëzes por ano a íngreme vereda da serra de Paranapiacaba, caminho que se chamou do Padre José, por tê-lo aberto êle mesmo, em 1560, em companhia de Afonso Sardinha e bom número de colonos e índios de São Paulo, por determinação de Luís da Grã e com o apôio de Mem de Sá (31). Ao Planalto o chamam pregações freqüentes, o govêrno de seus súditos, o interêsse pelos amigos, que são todos os habitantes de São Pau10. Um dia para batizar Clemente Alvares, como prometera as pais, outro para restabelecer a paz entre dois poderosos, Jorge Moreira e Afonso Sardinha. Mais uma vez, em 1570, para reconduzir ao seio da Igreja e da vida civilizada dois elementos rebeldes, homiziados entre os indômitos selvagens do Anhembí, Domingos Luís, o Grou e Francisco Correia.

A assistência às aldeias, Pinheiros e São Miguel, êle as torna então regular.

"Quanto aos gentios, escreve a 22 de abril de 1568 em São Paulo o Pađre Baltasar Fernandes, - dos Nossos que estão em Piratininga dois... se ocupam em visitar as aldeias, que estão umas duas léguas da povoação,

(30), - Doc. Hist., VI, 188.

(31). - H. A. Viotti, S. J., Do caminho do Padre José à via Anchieta, Jornal uo Commercio, Rio, 3 de julho de 1955. Acentuando o "favor" de Men de Sá para a abertura do caminho (Mon. Hist., III, 198.199), em nada se debllita a tese que nesse trabalho delxamos demonstrada. 
onde os Nossos vão num dia i vem no outro...; ensinam-lhes a doutrina e um Diálogo, que há na língua, ao pé da cruz que está dentro na aldeia, tangendo-se para isso a campainha primeiro" (32).

Esse Diálogo, sabemos já quem o compusera... Ir num dia e voltar no outro supõe dizer que já então existia, em Pinheiros e São Miguel um abrigo, onde pudessem passar a noite os missionários. Com o tempo se transformará êsse abrigo na "residência", cuja criação, referindo-se exatamente a Pinheiros, atribui o Padre Manuel da Fonseca ao "Venerável Padre Jusé de Anchieta". Igreja é o que ainda não existe, pois do contrário nela, e não junto ao cruzeiro no meio da praça, se ministrariam as lições de catecismo. Em 1580, todavia, estão já construídas as igrejas, como se vai ver.

O Catálogo jesuítico de 1574 nos fornece o nome dos catequistas nesse ano: Adão Gonçalves, antigo colono de São Vicente e soldado na expedição de 1560 contra a fortaleza de Coligny. E' o superior da casa, submetida à alta direção do Superior de tôda a Capitania, o Padre José de Anchieta. Bom missionário. Outro melhor ainda, inteiramente identificado com - meio e dos melhores "línguas" da terra, é o Padre Manuel de Chaves. Futuro imitador de Anchieta, acompanha-os na visita às aldeias, descalço, ora a um, ora a outro, o estudante jesuíta Agostinho de Matos, aprendiz da língua geral.

No mesmo ano de 1574, se iniciava no litoral, em circunstâncias providenciais, a catequese dos maromomís. Em janeiro de 1555, ausentes Anchieta e Nóbrega a despachar correspondência em São Vicente, capturaram em guerra os tupis de São Paulo um prisioneiro tapuia da tribo dos maromomís. Um guaianá, como na própria língua o denominavam os tupis. Um papaná, como o apelida Nóbrega e transcreve Polanco em Roma nus seu Chronicon. Maromimís, guarumimins, guarulhos são designações várias, aplicadas a essa mesma nação. Esses, os autênticos "guaianases" do século XVI, na Capitania de São Vicente.

Festivamente empenachado se preparava Tibiriçá para, em plena aldeia de São Paulo, sacrificá-lo em terreiro, quandc corajosamente intervieram os Padres Manuel de Paiva e Vicente Rodrigues e lho arrebataram das mãos. Desafogou o altivo chefe tupi frenèticamente a sua ira, mas 'acabou por

(32). - Carta de 22 de abrll de 1568, de Piratininga, Cartas Jes., II, 499. 
sujeitar-se, alguns dias depois, ao jugo dos mandamentos de Cristo. Quanto ao prisioneiro guaianá, após um tempo passado nc colégio dos jesuítas, evadiui-se para junto de seus parentes da serra de Jaguamimbaba. Baixando agora, com a sua tribo, para o mar, fôra ter à residência dos jesuítas de São Vicente, onde era superior Anchieta. Reconheceram-se.

Não sofreu o zêlo do superior pela conversão dos brasís perder tão boa oportunidade. Acompanhado pelo Capitão-mor, e levando em sua companhia ao antigo discípulo de Piratininga, agora Padre Manuel Viegas, dirigiu-se o Padre José, com o pequeno grupo de autóctones de língua travada, à fortaleza de Bertioga, a fim de localizar ali, junto à praia a uma légua para o Norte, o novo aldeiamento indígena. Interveio neste ponto, com a sua autoridade, o grande amigo de Anchieta, o capitão-mor Jerônimo Leitão (33) .

"Também não me esquece, expõe Frei Gaspar, em suas Memórias para a história da Capitania de São Vicente, que, no Arquivo do Convento de Nossa Senhora do Carmo da Vila de Santos, se conserva um auto de medição de terras e dêle consta que, ao Norte da relatada Fortaleza, em distância de uma légua, há um lugar a que chegaram os portuguêses, e teve princípio muitos anos depois da nossa povoação, sendo reitor do Colégio de São Vicente o Taumaturgo do Brasil: compunha-se de maramomís, que voluntàriamente buscaram a companhia dos portuguêses, e o Capitão-mor situou naquela paragem" (34).

Convinha ter em vista o precedente, para a boa interpretáção do que, poucos anos depois sucederá em favor dos índios dá Aldeia de Pinheiros e de São Miguel. Antes, porém, recordemos de relance a memorável despedida, que em 1577 lhe resrvou, ao Apóstolo de São Vicente, Jerônimo Leitão e o povo das duas vilas do mar, quando daí o tirou o provincial Inácio Tolosa. Cena tão comovedora de amor a um sacerdote da Companhia de Jesus, não creio se encontre em tôda a sua história.

(33). - Q. Caxa, Vida e morte do Padre José de Anchieta, Rio (1956), 50-51; P. Rolz (Rodrigues), Anchieta, Bahla, 1955, 35-37 e 207, sendo necessário, para malor exatidão, consultar a cópla manuscrita de Roma; Vasconcelos, Vida do Venerável, 1. III, c. 9, nn. 2 e 3, onde cita (1a. ed.) os Apontamentos do Padre José; A. de Alcântara Machado, Anchieta na Capitania de são Vicente, RIHGB, CV, 77-78.

(34). - Op. cit., 3a. ed., São Paulo (1920), 129-130. 
Luís da Fonseca, que a descreve, apela para outra despedida célebre, a de São Paulo em Mileto (35).

De São Vicente seguira para o Rio, para onde fôra nomeadc reitor do colégio. Ali não ficando, entretanto, seguiu com o provincial para a Bahia. Cogitando então Inácio Tolosa fazê-lo reitor ali, eis que de Roma chega sua nomeação para novo provincial do Brasil. Anchieta ocupou êsse cargo pouco mais de dez anos, desde 1577 até 1588. Desde êsse momento se faz novamente sentir sua autoridade na Capitania de São Vicente, para onde se dirige logo em 1578. Aqui estará novamente em visita no ano de 1579 e entre 1580 e 1581 , por alguns meses no Sul.

Durante a movimentada passagem da esquadra de Diogo Valdés pelas nossas plagas, permaneceu o provincial no Rio, desde março de 1582 até o segundo semestre de 1583. Sua presença concorreu para que tudo se passasse sem maiores inconvenientes. A São Paulo veio então mais de uma vez, logrando persuadir aos paulistas que, de sua já notável abundância agrícola e pastoril, consentissem em ceder os fornecimentos indispensáveis para a malaventurada expedição ao Estreito. Aqui estará êle de novo, com o visitador Cristóvão de Gouveia, nos primeiros meses de 1585 . Como provincial, suas últimas visitas se dão no ano de 1587.

Escoa-se então um lustro sem que Anchieta retorne à sua amada Capitania de São Vicente, consagrado agora ao cultivo espiritual da Capitania do Espírito Santo, onde é superior. Constituído, todavia, em fins de 1592, pelo provincial Beliarte, visitador das casas do Sul, fixa-se no Colégio do Rio de Janeiro, donde, em 1593 e 1594, estende as suas visitas até São Paulo. $\mathrm{Da}$ fundação da Cidade, em que tomara parte saliente, até 1594 , vão precisamente quarenta anos, em que a sua ação benfazeja ganhou para sempre o coração de seus habitantes. Anchieta é nosso: - São Paulo não o renegará! Dessa atuação não se furtaram, evidentemente os aldeiamentos cristãos, assistidos pelo ministério sacerdotal dos jesuítas.

Com o ano de 1580, atinge a história das aldeias do padroado real em São Paulo um dos seus momentos mais expressivos. Documento sôbre todos momentoso, relativamente ao desenvolvimento orgânico da obra misssionária dos jesuítas no

(35). - H. A. Viotti, S. J., Alguns documentos inéditos sóbre o Padre Anchieta, Rev. de História, $X$ (1959), $n$. 39, 19-31. O fato não vem mencionado na Hist6ria da Companhia de Jesus no. Brasil... 
Planalto, é a Carta de Sesmaria, lavrada a 11 de outubro de 1580, em São Vicente, por outro amigo íntimo de Anchieta, o tábelião Antônio Rodrigues de Alvarenga. Por ela concedia Jerônimo Leitão "para todo sempre" duas vastas glebas de terra aos índios da Aldeia de Nossa Senhora dos Pinheiros e de Aldeia de Ururaí.

"A mim me mandaram dizer, assevera Jerônimo Leitão, os indios de Piratininga e das aldeias dos 'Pinheiros e de Urureins, por sua petição".

Petição escrita! E, o que mais é, englobando requerimento de índios de duas aldeias diversas, que teriam conferido entre si suas pretensões... Segue-se a série de razões particularmente lógicas e bem expostas:

"visto... suas razōes serem justas", - reconhece o capitāo-mor. "Outrossim a maior'parte dêles serem cristāos e terem suas igrejas, e estarem sempre prontos a defenderem a terra e a sustentá-la, o que fizeram assim em meu tempo, como dos capitães passados, pela informação que disso tenho" (36).

Nestas derradeiras frases vemos assinalada a intervenção dos índios das Aldeias de Pinheiros e de São Miguel na expedição de 1575 contra os tamoios de Cabo Frio, em que o auxílio militar da Capitania de São Vicente, comandado por Jerônimo Leitão, teve considerável importância. Pode haver também alusão a certa guerra havida em São Paulo em 1578, de que não remanesceu senão breve referência documental, -... revela a História da Companhia de Jesus no Brasil.

Tal requerimento é da autoria de quem, possuindo competência para redigí-lo, estava sumamente interessado no bem espiritual e material dos rudes filhos das selvas. Presente então no Sul, neste fim do ano de 1580 , o provincial Anchieta, a êle, antes que a outrém ninguém, se há de atribuir a diligência. Razä̉o a mais para que a essa petição acudisse prontamente o capitão-mor, com o despacho favorável:

"dou aos suplicantes, no lugar aonde pedem, seis léguas de terra... em quadra, no sitio aonde pedem, que é Carapicuíba ao longo do rio Imbuaçaba, tanto de uma parte como de outra..., aos moradores da dita Aldeia dos Pinheiros".

36). - Boletim do Dep. do Arq. do Est. de S. Paulo, V, 55-60; Registro Gera da Cám. Mun. de S. Paulo, I, 354-356; Cartas de datas de terra, 1, 21-24. 
Aos de Ururaí, outras tantas ao longo do rio homônimo, contíguas à Sesmaria de João Ramalho (37) .

Acusa o precioso documento a existência de igrejas em ambas as aldeias. Entre 1568 e 1580, intervalo em que foram construídas, temos que Afichieta era o superior dos' jesuítas em São Vicente, até 1577, e dêsse ano em diante provincial do Brasil. Seu provincialado se caracterizou pela expansão da atividade missionária em tôda a parte, Bahia e Pernambuco, Paraíba e Rio de Janeiro, sobretudo no Espírito Santo. Nada mais natural, portanto, que atribuir ao Padre Anchieta tal aperfeiçoamento da catequese em São Paulo. Nem há documento algum, que contradiga as afirmativas de Frei Agostinho de Santa Maria e do Padre Manuel da Fonseca, reforçadas mais tarde por Azevedo Marques, Rodolfo Garcia e Afonso de Taunay (38).

Após quase seis anos na direção da Província religiosa dos jesuítas no Brasil, ao regressar no segundo semestre de 1583 à Bahia, lá foi encontrar Anchieta ao visitador Cristóvão de Gouveia, chegado a 9 de maio, em companhia do Padre Fernão Cardim, seu sócio e que se notabilizaria entre nós, como escritor e homem de govêrno. Traz-lhes o provincial notícia dc que se passa nas Capitanias do Sul. Com êsses esclarecimentos, é compilado o Catálogo e as informações anexas, que, assinadas por Cristóvão de Gouveia, nesse mesmo ano, vão remetidas para Roma.

Sôbre as aldeias de São Paulo aí se diz:

"Visitam mais os Nossos desta casa duas aldeias de índios, todos os domingos, dizendo missa nelas, ora em uma, ora em outra, por faltar sacerdotes, e aí ensinam a doutrina cristá, pregam, confessam e batizam os indios" (39).

Pelo Catálogo do ano seguinte, ficamos sabendo que, em São Paulo, o superior é João Saloni,

\footnotetext{
(37). - F. de Assis Carvalho Franco, Os capitáes-mores vicentinos, em Rev. do Arq. Mun. de S. Paulo, (RAMSP), LXV, 44: A. Alcântara Machado, Anchieta na Capitania de São Vicente, RIHGB, CV, onde se deixa, em vá. rias passagens, Indicada a colaboraçáo entre Anchleta e Jerônlmo Lettão.

(38). - Azevedo Marques, Apontamentos, 2a. ed., II, 171; Rodolfo Garcia, em Tratados da terra e gente do Brasil, Rio, 1925, 412, nota IXXXIV; Afonso de Taunay, S5o Paulo no século XVI, Tours, 1921, 35.

(39). - Bras. 5, 40. Texto em castelhano.
} 
"línguas" e por isso mesmo encarregados das aldeias Leonardo do Vale, Manuel de Chaves e Pantaleão. Gonçalves; aprendizes de tupi, Tomás Fields e Jerônimo Soares" (40).

Saloni e Fields serão enviados por Anchieta ao Paraguai, em 1586.

$\mathrm{Na}$ Breve informação do Brasil e suas Capitanias, que Anchieta escreve em 1584, para uso do historiador da Companhia, Padre Pedro Maffei, residente então em Lisboa, acrescenta-se esta informação: os índios das doze aldeias que, por volta de 1560, existiam nos arredores da Vila de São Paulo de Piratininga,

"agora estão, quase juntos todos em duas: uma está a uma légua, outra duas, cada uma das quais tem igreja e é visitada dos Nossos, como acima se disse" (41).

Esclarece, por sua vez, a Informação da Província do Brasil para Nosso Padre, escrita em 1585 por Fernão Cardim:

"Têm duas aldeias de índios a seu cargo: uma intitulada da Conceiçã̃o de Nossa Senhora dos Pinheiros, que dista uma légua da vila, e outra intitulada de São Miguel, que dista duas léguas. Entre ambas terão 1.000 pessoas e há nesta terra muito bom aparelho para conversão, por haver grande número de gentio não muito longe" (42).

Mas não era apenas uma questão de número...

O "bom aparelho para conversão" resultava especialmente de um fenômeno histórico todo peculiar a São Paulo. Enquanto nas demais capitanias as relações entre brancos e índios se haviam revestido quase sempre do caráter da violência, guerra de extermínio e assalto escravizador de uma parte, emboscadas e investidas incendiárias, em represália, de outra, com a conseqüente decadência das emprêsas de colonização, - em São Paulo, descontada a luta contra os tamoios até 1567, as relações entre os colonos e os tupis do Campo foram de intercâmbio cordial.

"Os portuguêses trabalham muito por conservar sua amizade",

\footnotetext{
(40). - Bras. 5, 31-32.

41). - Cartas Jes., III, 321.

(42). - Cartas Jes., III, 424.
} 
escreve Anchieta (43). "Parceiros e compadres" é a expressão pitoresca, com que Frei Gaspar traduz os têrmos dessa feliz aliança.

No tocante à catequese dos selvícolas, pondera Anchieta:

"A conversão dêstes não cresceu tanto como na Bahia, porque nunca tiveram sujeição, que é a principal parte necessária para êste negócio, como houve depois na Bahia, em tempo do governador Men de Sá. Mas contudo perseveram até agora". E mais esta valiosa observação: "São em certa maneira mais que louvar, porque tudo quanto dão de si é voluntário, sem mêdo de ninguém, porque ainda agora aquela gente está intacta, sem sentirem as tiranias dos portuguêses, nem creio que lhas quererão sofrer". "Vivem como cristãos e trazem outros seus parentes do sertắo a morar consigo, para também receberem a fé" (44).

Entre os "senhores naturais" de Piratininga e os povoadores adventícios se estabelecera o equilíbrio pacífico, de que os jesuítas, Anchieta sôbre todos, constituiam o poder moderador e benquisto. O parentesco, aliás, entre índios e brancus era dos mais intensos. Em 1585, não encontrara Cardim em São Paulo mais que uma senhora nascida em Portugal, tôdas as mais eram mestiças. Ia-se forjando no Planalto a raça vigorosa e andeja, destinada ao avassalamento do território brasileiro. De 1585 em diante é que se vai alterar o panorama, sobretudo depois e à medida em que se vai ausentando de Piratininga o seu patriarca espiritual, José de Anchieta.

Não poderia ser mais entusiástica a impressão que, em São Paulo, colheu Fernão Cardim, aqui chegado com o visitador e o provincial, para a festa de 25 de janeiro de 1585 , recebidos na "peaçaba" de Ibirapuera por luzida escolta de cavaleiros. Páginas de anotolgia, as que traçou a respeito em a Narrativa Epistolar (45). Da visita às aldeias, tendo já descrito as festas da Bahia e do Espírito Santo, anota aqui lacônicamente:

"Foi (o visitador" a uma Aldeia de Nossa Senhora dos Pinheiros da Conceição. Os índios o receberam com

\footnotetext{
(43). - Cartas Jes., III, 317.

(44). - Cartas Jes., III, 316-317.

(45). - Tratados da terra e gente do Brasil, Rio, 1925, 352-357.
} 
muita festa, como costumam, mandando de sua pobreza. Também foi a outra aldeia daí duas léguas, parte do caminho navegando... Nesta aldeia (de São Miguel) batizou o Padre trinta adultos e casou na lei da graça outrostantos" (46).

Acompnhava ao visitador o provincial, durante essa visita às capitanias do Sul (47). Como lhe impunha sua humildade, rucolhia-se modestamente à sombra da autoridade superior, deixando-a inteiramente à vontade. Só por exceção menciona Cardim sua presença, para lhe traçar o conhecido e lapidar elogio. Gouveia, que, noutro encômio memorável, lhe não negou o reconhecimento le sua santidade e prudência de govêrno, não é crível que ، ’ixasse de conferir com Anchieta as providências cabiveis, para conduzir as coisas a uma perfeiçã̃o maior (48).

Resultado sem dúvida de uma consulta, em que opinou autorizadamente o provincial, foi a medida então assentada em relação às aldeias de São Paulo: estabelecer em ambas residência missionária estável. Lástima foi que, nessa mesma oportunidade, desse o visitador por comprovada a falta de pesscal idôneo para essas residências (49). No ano seguinte, aliás, crderia o Brasil em favor do Paraguai quatro missionários: Saloni, Fields, Ortega e Leonardo Armínio. Coube à São Miguel, mais distante, ser então provida com o Padre Diogo Nunes, notável evangelizador, natural de São Vicente, que, no Catálogo de 1586, aí aparece, em companhia do estudante Custódio Pires $(50)$.

Para a assistência religiosa à Nossa Senhora da Conceição dos Pinheiros, que exatamente dessa época em diante teria substituído o seu orago para Nossa Senhora do Rosário, como atrás notamos, estavam em São Paulo, como catequistas nesSt. ano de 1586 o Padre Manuel Viegas, o fundador da Aldeia d. Nossa Senhora da Conceição dos Guarulhos, e o Padre Leonardo do Vale. Nesse ano ausentara-se para São Vicente o

\footnotetext{
(46). - Ibidem, 355

(47). - "Dall a pouco nos partimos para o Rio de Janeiro", Anchieta, Resposta ... ao Padre Gonçalo de Oliveira, Cartas Jes., III, 464

(48). - H. A. Viotti, S. J., A causa de beatificaçáo, Rlo, 1953, 5. "E' êste Padre um santo de grande exemplo e oração, cheio de tôda a pèrfeição, desprezador de si e do mundo, uma coluna grande desta Província" (Cardim). H. A. Viotti, S. J., Anchieta e o Mar, Verbum, XV (1957), 151: "Vir fidelis, prudens et humllis in Christo e de todos muito benquisto, sem que haja nlnguém que dêle tenha queixa; nem achar posso palavra (49). - S. Leite, I, 261 . ou ato que tenha praticado mal" (Gouveia).

(50). - Bras. 5, 46 .
} 
Padre Manuel de Chaves, o mais assiduo dos missionários das aldeias paulistas:

$\mathrm{Na}$ apreciação do provincial Beliarte, sucessor de Anchieta, foi Manuel de Chaves dos melhores operários que teve a província do Brasil para a conversão do gentio (51). Possuindo longa prática da língua geral, empenhou-se durante quarenta anos (1550-1590) nesse apostolado, a maior parte do tempo em São Paulo. Escrevendo-lhe a biografia diz Anchieta ser êle quem

\begin{abstract}
"suspendia os arcos guerreiros entre os indios e os portuguêses. Nunca jamais, enquanto esteve em Piratininga, se abriu guerra entre uns e outros. Uma só vez se ausentou e foi o mesmo que rompesse a guerra, que com sua presença depois parou, durando a paz tôda a sua vida, e acabando-se com a sua morte" (52).
\end{abstract}

Até essa altura, do ano de 1585, como atrás foi dito, desł nvolvia-se orgânicamente em São Paulo a catequese, que St: teria coroado então com o estabelecimento de residências estáveis, não fôsse a escassez de pessoal. Dispondo agora de vastíssima gleba privativa, possuia cada uma das aldeias os elementos indispenáveis para viver folgadamente. Tudo favorecia a observância dos preceitos cristãos e a vida sacramental. Contando cada qual cêrca de 500 habitantes, constituiam fôrça mobilizável para o serviço de El-Rei e abundante mão de obra paga, para as atividades agro-pastoris dos mor:'dores. Sob a direção dos brancos, eram êles que corriam com a tarefa da conservação dos caminhos e do transporte das cárgas pela serra do Cubatão.

Reinava a paz e a prosperidade. E à sombra dessa paz, fioresciam nos arredores da vila, até boa distância, as fazendas dos portuguêses. Primeira etapa na marcha da civilização rumo do Oeste era a povoação de Parnaíba, que se fundava por essa época. Para ela se ia pelo caminho de Pinheiros e, antes do fim do século, já se fala em ponte no Emboaçaba.

Ao longo dêsse caminho, estava situada a vasta propriedade de Fernão Dias, o velho, abrangendo boa parte das terras altas do Caaguaçú. Passando o Jurupatuba, no Butantã,

(51). - Lus. 71, 4, cit. em S. Leite, I, 294, nota 2.

(52). - Vasconcelos, Vida do Venerável, 1. I, c. 8, nn. 2-5, reproduzindo os Apontamentos do Padre José. Az. Marques, Apontamentos, 2a. ed., II, 92-93. 
se espraiavam na planície os canaviais de Afonso Sardinha. Aí funcionva um trapiche para a fabricação do açúcar. Dos muitos marmeleiros, que cresciam pelas encostas, se industrializavam as marmeladas, que em caixas se exportavam para o mar. Junto à Aldeia de Nossa Senhora dos Pinheiros, criava Alvaro Neto as suas ovelhas, Antônio Bicudo e João do Prado desenvolviam suas lavouras e criações (53).

Trigo e cevada concorriam com a farinha da terra, o alimento por excelência do autóctone e seus descendentes mamelucos. A uva, o figo, a romã, os melões, a laranja e os limões, frutas importadas da Europa, pejavam os pomares ainda novos. Para elas e para as flores, o viveiro era a horta do Colégio. Porcos, vacas e cavalos se misturavam aos ovinos, enchendo os campos, opulentados pela bênção do trabalho. São Paulo era já o celeiro, de que se aprivisionava o litoral. Sua produção ia alimentar o Rio de Janeiro e, por vêzes, socorrer a Bahia e o Rio da Prata. Resultado tudo isso da paz. E da vida pautada nos ditames do Cristanismo, através das lições de Anchieta...

A direção dos acontecimentos, a esta altura, sofre uma guinada de 180 graus. Numa brusca mudança de cena, saimos dessa bucólica serenidade, para ouvir doravante o estrépito dos combates. Com o pretexto do morticínio de Pero Lobo (1532), do martírio de Pero Correia e João de Souza (1554) e da morte de 150 europeus nos últimos quarenta anos causćda pelos carijós, alegando sobretudo - aqui, sem dúvida, a causa verdadeira! - a falta de braços escravos, requeriam nesse ano de 1585 os moradores de Santos e São Vicente ao Capitão-mor Jerônimo Leitão, sob a ameaça de desampararem a capitania, movesse guerra contra o dito gentio (54).

A princípio visavam tão sòmente aos carijós e a expedição seria por mar até Paranaguá. Depois, por influência dos habitantes do Planalto, abrangeu também aos tupiães e outros selvagens, que se deparassem, tomando o caminho do sertão. Fêz-se a guerra, que durante nove meses se desenrolou né direção do Guairá. Paranambaré, no interior do atual Estado do Paraná, parece ter sido ò ponto final da entrada guer-

(53). - A. de Taunay, São Paulo no século XVI, Tours, 1921, 213; T. Sampaio, São Paulo de Piratininga no fím do século XVI, RIHGSP, IV, 262.

54). - Atas da Câmara Municipal de são Paulo (ATAS), I, 275-282; Pedro Taques, História da Capitania de São Vicente, (São Paulo, s. d.), 67. 
reira. Antecipando-se à organização das reduções jesuíticas, penetravam os paulistas até as proximidades de Vila Rica e Ciudad Real (55).

À volta, parece ter havido choque com os tupiniquins sertanejos. Com os tupiães entra em contacto Domingos Luís, o Grou e os convence a abalar pacificamente para as vizinhanças de São Paulo. O espetáculo da leva de escravos carijós, embora contrários, não deixaria de "escandalizar" aos aliados... Estremecia o equilíbrio pacífico. Em breve se levantaria a indiada feroz do Anhembí, ameaçando a vila de Piratininga.

Por êsse tempo, últimos meses de 1587, partia de São Paulo a expedição exploradora de Antônio de Macedo e Domingos Luís, o Grou. Compunha-se de 50 homens brancos e mamelucos, escravos e índios forros, envolvendo, segundo parece a tribo dos tupiães, que sempre viera em som de paz. Pelos testemunhos de Ascenço Ribeiro, que nela tomou parte, de Mateus Luís Grou, Clemente Alvares, Luís Anes, o moço e outros, nos Processos anchietanos, teria permanecido cêrca de sete anos no interior do país, embrenhando-se por centenas de léguas e regressando, dizimada, em dezembro de 1593 (56).

Pelas referências, que se lêm nas Atas da Câmara, onde aparecem os topônimos de Mogí, de Jaguarí e de Paranaíba, to ria a notável Bandeira seguido no rumo do Noroeste. Penetrando no mínimo 200 léguas, ou sejam 1.200 quilômetros, bem pode ter atingido o centro de Goiás ou o Norte de Mato Grosso. Correra boato em São Paulo de que a expedição teria sido destroçada pelos índios. No regresso, não muito longe de Piratininga, houve de fato um recôntro, em que pereceram os dois: chefes e mais alguns entradistas, em sítio, que se denominou da: "Traição".

Ao chegar, nos primeiros meses de 1587 a São Vicente, e ouvindo o eco de todo êsse tropel mavórtico, apressou-se Anchie-

(55). - ATAS, I, 279, 281, 285, 297, 301. Na interpretaçāo destas referências das Atas, seguimos Américo de Moura. Para o têrmo da expedição, v. $P$. Pastells, História de la Companhia de Jesus en el Paraguay, Madrí, 1912, I, 195: "antes de llegar a Paranambaré... le llegó la nueva de como en. traban por el camino que Jerónimo Leytón havia entrado 30 años atrás gran golpe de portugueses" (Carta de D. Antônio de Añasco, de 14 de. novembro de 1611).

(56). - H. A. Viotti, S. J., O processo remissorial de 1627-1623 em São Paulo, RAMSP, CLIX, 210-211. Mateus Luís Grou, fala em 407 léguas. No seu depoimento de 11 de abril de 1622 (Processo Informativo de são Paulo), declara, por sua vez, Luís Anes (que nessa expedição perdeu o pai, Luís Anes, o velho, e o avô, Domingos Luís, o Grou) que os expedicionários se embrenharam 300 léguas no interior. 
ta em recambiar para São Paulo ao veterano Manuel de Chaves, que viesse a suspender de novo aquêles arcos e êstes arcabuses. Alquebrado, esquelético e quase cego, não cessou, nos três anos que lhe restaram de vida, o benemérito jesuíta de jornadear a pé, de uma para outra aldeia, por vêzes em jejum, ora galgando encostas empinadas, ora atravessando águas frigidíssimas (57). A 18 de janeiro de 1590, descansava para sempre Manuel de Chaves. Com êle se finou também o período da paz.

Com a chegada finalmente de Marçal Beliarte à Bahia em janeiro de 1588, e após o aviso que de lá se remeteu ao Espírito Santo, onde então se encontrava, deixou José de Anchieta o provincialado, cargo que exercera pouco mais de dez anos. Fixou-se então naquela capitania, só voltando a São Paulo cinco anos depois. Nesse meio tempo, acabou de romper-se o equilíbrio das relações pacíficas entre os paulistas e os índios do sertão. E as aldeias cristãs de São Paulo se viram envoltas nc pó da refrega. Haviam atingido exatamente, em 1589, sua maior prosperidade: São Miguel contava nesse ano 800 almas, Nossa Senhora dos Pinheiros, 600 (58).

Em março de 1590, informava a Câmara ao Capitão-mor sôbre más novas, vindas do sertão. Já em abril, por haver tumbém entre os índios das aldeias "alguns alevantados" e, sendo necessário velar para que os aldeiados se mantivessem fiéis, cuidava Jerônimo Leitão de nomear para capitão da Aldeia de São Miguel a Gaspar Colaço Vilela (59). A 7 de julho, requeria concitadamente o procurador do Conselho, João Maciel, aos oficiais da Câmara reclamassem do capitão-mor pronta e enérgica intervenção militar contra os selvagens do interior que, sublevados, haviam posto a capitania "a ponto de se perder".

"Mataram três homens brancos e feriram outros muitos e mataram muitos escravos e escravas, índios e índias cristãos e destruiram muitas fazendas, assim de brancos como de índios, e queimaram igrejas e quebraram a imagem de Nossa Senhora do Rosário dos Pinheiros".

$\mathbf{E}$ eram os antigos "compadres e parceiros"! Tornava-se indispensável rápida e escarmentadora campanha punitiva (60).

(57). - Lus. 71, 4, cit. por S. Leite, I, 294, nota 2.

(58). - Bras. 5, 54 .

(59). - ATAS, I, 388-390; Registro geral, I, $21-22$.

(60). - ATAS, I, 403-404. 
Autor do sacrílego atentado fôra um índio apóstata da Aldeia dos Pinheiros. Aprisionado no contra-ataque, desfechando com os reforços prontamente enviados do litoral, foi arrastado pela aldeia, atado à cauda de um cavalo (61). Pinheiros detivera a belicosa vaga do sertão, barrando, muito à sua custa, o assalto contra a vila, de que era ante-mural.

Verifica-se então uma segunda guerra de Jerônimo Leitão, agora contra os ferozes tupiniquins sublevados do vale do Anhembí. A primeiro de janeiro de 1591, lavraram um têrmo os Oficiais da Câmara de São Paulo para dar a razão por que há cinco meses se não reunia a edilidade paulistana:

"Por serem idos à guerra com o Sr. Capitão, e não haver ocasião, nem oportunidade para isso, nem gente na terra" (62).

Durante êsse tempo, desde fins de julho de 1590 , andara Jerônimo Leitão assolando as alderas do Tietê... Assoalhou$\mathrm{Se}$ mais tarde, no ambiente das missões espanholas, que foram 300 as aldeias e 30.000 índios os que, durante seis anos, se viram destruídos. Parece haver nissơ não pouco exagêro...

Daí por diante, todavia, com o motivo da ameaça do sertão contra São Paulo, a guerra (ofensiva ou defensiva, pouco importava), se tornou uma obsessão. Nela enxergavam os moradores' de São Paulo o grande meio de capturar escravos, vantagem que, durante mais de um século, compensaria os riscos das mais temerárias aventuras em paragens longínqüas e desconhecidas. Em relação aos jesuitas, que se opunham necessàriamente a essa política, em nome da missão civilizadora de que os encarregara a Metrópole, principiou com isso a arrefecer, da parte de uma facção dos paulistas, a admiração e sincera amizade que, durante todo o século XVI, os unira aos fundadores da cidade (63).

Essa explosiva questão da liberdade dos índios, comum aliás com o caso das possessões espanholas, surgira desde o primeiro contacto dos colonizadores lusos com a população aborígene, ainda antes da criação do sistema das capitanias. No Regimento de Tomé de Souza, preceituava por isso mesmo El-Rei:

(61). - Bras. 15, 366-366v. A Annuac Litt., 1590-1951, 826827. Apud S. Loite, I, 294; cf. 264 , onde a data se altera para 1598, por engano- v. Igualmente S. Lelte, VI, 584585; Azevedo Marques, Apentamentos, 2a. ed., II, 20-28. (62). - ATAS, I 400 .

(ब). - S. Laite, 1, 311 e 313 . 
"Hei por bem que daqui em diante pessoa alguma de qualquer qualidade ou condição que seja não vá saltear nem fazer guerra aos gentios..., sem nossa licença ou do Capitão da Capitania de cuja jurisdição fôr"... "Sem a dita licença..., incorrerão em pena de morte" (64).

Para uns tantos aventureiros - não falo aqui da gente honrada que, desde os primeiros tempos Portugal enviou a povoar esta nossa terra - , para os degredados que de lá também vieram, o bom método de "fazer a América" era agrilhoar os naturais do Pindorama, impondo-se pela astúcia ou a superioridade das armas, e constrangê-los a labutar no eito em benefício de seus novos patrões, sob pena de açoites e outras crueldades. O ódio visceral que tais processos despertavam nas tribos indígenas, as distanciava de tudo quanto representasse a "civilização" dos invasores.

Sob pena do mais rotundo fracasso em sua missão civilizadora, teriam que opor-se os evangelizadores cristãos a semelhantes injustiças. Ao lado seu estavam as leis humanas e as divinas. Honra do Cristianismo foi ter suscitado quem mantivesse nessa altitude moral o penoso cumprimento do dever. Honra da História pátria é de haver, com a fina flor de seus cultores, um Rio Branco, um Oliveira Lima, um João Ribeiro, um Capistrano de Abreu, um Afonso de Taunay e outros mais, proferido no tribunal de sua justiça a sentença, que glorificou os mártires dêsse nobilíssimo dever para com a humanidade.

Estimulado, sem dúvida, pelos brados dos missionários, entre os quais se destacou o desassômbro de um Manuel da Nóbrega, decretava, a propósito o Rei Dom Sebastião:

"Defendo e mando que daqui por diante se não use nas ditas partes do Brasil do modo que se até ora usou em fazer cativos os ditos gentios, nem se possam cativar per modo nem maneira alguma, salvo aquêles que forem tomados em guerra justa, que os portuguêses fizerem aos ditos gentios com autoridade ou licença minha ou do meu governador nas ditas partes, ou aquêles que costumam saltear os portuguêses, ou a outros gentios para os comerem" (65).

Contra essa léi de 20 de março de 1570 se levantaram imediatamente no Brasil as contradições. Menos em São Paulo,

(64). - HCPB, III, 348 .

65). - Boletim do Conselho Ultramarino, Leg. antiga, I, (Lisboa, 1867), 127; Varnhagen, Hist. Geral, 4a. ed. integral, São Paulo,..1948, I, 407-408; $\mathrm{S}$. Leite, II, 207. 
onde o problema, como por milagre de Anchieta, andava; então e por muitos anos ainda, perfeitamente sopitado. Quatro aros depois era derrogada a lei, em favor dos caçadores de es.cravos... Em 1587, revigorava Filipe II a mesma lei, introduzindo novas modificações (66). Permanecia de pé, contudo, o princípio: os filhos da América eram por natureza livres e, sem justa causa, determinada em lei, não poderiam ser prividos de sua liberdade.

A eficácia de tais medidas legislativas era muito relativa. Dependia quase sempre da energia e da sinceridade, nem sempre reais, com que as aplicavam no Brasil os prepostos de Sua Majestade. E, de mais a mais, entre o legislador e os vassalos, a que elas obrigavam, havia de permeio o Oceano. Em São Paulo, por cima, a inacessível muralha da Paranapiacaba, obstáculo que, sobretudo no século XVII, foi o pedestal da semiautonomia dos paulistas. Por isso mesmo, de tempos a tempos, iám impetrando os jesuítas novas leis de proteção aos seus pupilos (67), já que as antigas haviam caído em desuso. Mas quem, crom olhar profético, soube ver todo o trágico sentido do problema (que ainda hoje perdura, em novos têrmos), foi o Apóstolo do Brasil.

A 7 de setembro de 1594, recém-chegado à Capitania do Espírito Santo, donde já não mais sairia, dava conta ao geral Cláudio Acquaviva de sua comissão como visitador, em nome dc ex-provincial Beliarte, nas capitanias do Sul. No Espírito Santo, encontrava perturbação não pequena entre os portuguêses, entre si por ambições pessoais, e com os jesuítas,

"porque não Ihes concedemos que façam dos indios cristãos à sua vontade, querendo servir-se dêles a torto e a direito: Mas como esta é guerra antiga e no Brasil não se acabará, senão com os mesmos índios, trabalhase todo o possível pela sua defensão, para que com isso se salvem os predestinados, que se não se tivesse respeito a isto era quase insofrível a vida dos Padres nas aldeias. Sed omnia sustinemus propter electos" (68)!

(66). - Arquivo Histórico Colonial, Registos, I, 45-47v. Apud S. Leite, II, 211.

(67). - Lei de 1596, de Filipe II (S. Leite, II, 623-624); Lei de 1609, de Filipe III (S. Leite, V, 3-5); Lei de 1611, do mesmo Rei (S. Leite, V, 8 e 19-20); Breve Commissum nobis, de Urbano VIII, de 1639 (S. Leite, VI, 251-252); Lei de 1655, de D. João IV, obtida por Antônio Vieira (S. Leite, IV, 53); Lei de 1680, do Regente $D$. Pedro; obtida igualmente por Vieira (S. Leite, IV, 63-67):

(68) . - Cartas Jes., III, 291. 
Nessa mesma carta, dava notícia da situação em que deixava a Capitania de São Vicente, na qual ainda nesse mesmo ano estivera, recebendo a profissão do Padre Pero Soares, superior aqui dos jesuítas. Era-o em São Paulo o Padre Domingos Ferreira. Corriam bem os ministérios, seja com os portuguêses, seja com os brasis.

"Ainda que, como a capitania por uma parte foi saqueada dos inglêses (refere-se aos dois assaltos de $\mathrm{Ca}$ vendish a Santos e São Vicente em 1591 e 1592), e por outra parte se levantaram alguns brasis do sertão e mataram alguns homens, não tenham a quietude desejada para a doutrina, sempre se visitam, confessam e êles ouvem missa e recebem os demais sacramentos, com não pouco trabalho dos Nossos, que são poucos para acudir a êles e aos portuguêses e escravos" (69).

De uma visita a São Paulo, por outubro-novembro de 1593, foram conservados nos Processos anchietanos dois flagrantes, cclhidos na Aldeia dos Pinheiros. A porta de sua igreja de taipa, o procurara uma índia. Vinha chorando a sorte lutuosa do marido, engajado fazia sete anos na expedição de Macedo e Grou. Constava serem todos mortos... - Não chorasse, foi a resposta do velho missionário: era vivo e dentro em pouco o teria em casa de volta (70)! E saiu a percorrer os caminhos que se alongavam pelo campo.

Ao passar junto à porteira do sítio de Alvaro Neto, avistaram-no e acudiram pressurosos os donos da casa, Alvaro e sua espôsa Mência da Penha. Morriam-lhes os escravos e os rfabanhos estavam sendo dizimados. Reflexo sem dúvida da guerra com os selvagens. Já não teriam dote para a filha casadoura, que atingia então seus quinze anos. - Não necessitava de dote essa menina, retrucou o Padre José: dentro em pouco a chamaria Deus para os esponsais eternos. E entrou e lhe falou, à jovenzinha, do céu que a esperava. Mais alguns dias e ela falecia (71).

fndios das Aldeias de Nossa Senhora dos Pinheiros e de São Miguel haviam participado daquela primeira grande entrada bandeirante... Renunciariam os paulistas a continuar a

\footnotetext{
(69). - Ibiaem.

(70). - Asv, Congr. Rit., n. 305, Processo Apost. de Săo Paulo, ano de 1627, f1s. $51-54$.

(71). - Arquivo da Pogtplagio das causas das servos de Deus da Companhin de Jesus em Rome, Proceseo . Inf:. de sto Paulo (1622), depotmento de Alvaro Neto, As. 116v-117, depolmento de Mencta de Penha, A. 129a.
} 
servir-se dêles à sua vontade? A mão-de-obra paga, que neles teriam, continuando sob a administração dos jesuitas, preferiram contar com auxiliares gratuitos, para a conquista das "nações" do interior... Numa afirmação de crescente independência, admitindo temporàriamente ainda a autoridade, mais próxima e flexível, do capitão-mor, Câmara e povo de São Paulo, usurpam daí por diante nessa matéria a jurisdição real, enfeixada nas mãos do governador geral. Isso, desde a morte de Dom Francisco de Souza principalmente, até princípios do século XVIII.

Em 1592 recusam em ajuntamerte público fazer entrega de administração temporal das aldeias aos jesuitas conforme provisão do novo Capitão-mor Jorge Correia (72). Nessa reunião, esclarecendo o que se passava no resto do Brasil, onde era êsse o regime, vota, entretanto, o novo vigário de São Paulo, com a maioria, baseado na inoportunidade da medida, em vista da iminência de guerra e do perigo de alvoroto entre os aldeiados. Ex-aluno dos jesuítas, em São Vicente e no Rio, provàvelmente também na Bahia, tendo assistido no Rio em 1583 à cura de sua mãe, Isabel Afonso, entrada em agonia, pelo Padre José de Anchieta, teria o Padre Lourenço Dias Machado apoiado certamente a dita providência, se a essa altura estivesse aqui presente o Taumaturgo do Novo Mundo (73).

Com a sua veneranda presença na Capitania, em 1593, opinará, em sessão da Câmara a 3 de outubro, o vigário forâneo dн Santos, Padre Jorge Rodrigues, contra a conveniência no momento de uma nova campanha a ser levada a cabo contra os índios do sertão pelo citado capitão-mor Jorge Correia, por dizerem

"os Padres da Companhia que se não podia fazer a guerra" (74).

Prevalecia nesse instante o partido da paz. Desejando preservá-la também com os moradores de São Paulo, procuravam, entretanto; os jesuitas, sem abdicar dos princípios, ceder na prática, sempre que fôsse lícito fazê-lo... Modificadas daí a pouco as circunstâncias, capitaneou Jorge Correia a nova guerra.

(72). - ATAS, I, 446-448; Mons. Paulo Florenclo, A Igreja na Historia de são Paulo, São Paulo, 1952-1953, I, 137-139.

(73). - ASV; Congr. Rit., n. 303, Processo inf. da Bahla (1619), fls. 115-117, depolmento do Padre Pero Leitazo; testemuntha de vista nessa visita de Anchieta à casa de Rui Dias Machado; apresenta ainda o depoimento do Padre Lourenço Dias Machado, dado em 1611 na Bahla perante Dom Constantino Barradas, que também o assina.

(74). - ATAS, I, 470-472. 
Já não mais se restabeleceria o antigo equilíbrio, a tranqüilidade da ordem existente até 1585. O ímpeto escravagista, tanto tempo sopitado, irrompera em meio a êsse tumulto, com redobrado vigor. A incoercível expansão paulistana, que durante pouco mais de um século estará unida a essa finalidade censurável, era agora um fato, que as circunstâncias do Mundo, da América, do Tempo e da História poderiam explicar. Desaparecia na distância a doce figura de Anchieta, prestes a extinguir-se suavemente em Reritiba... E a paixão guerreira, a ambição do mando, a cobiça da riqueza, escondida no leito dos riachos, ou disponível nas tabas da floresta virgem, incendiavam a imaginação dos paulistas.

Como pedras que se desprendem da montanha e fatalmente rolam até o fundo da torrente, uma após outra largavam de São Paulo as Bandeiras, rumo do Oeste, do Sul ou do Norte... Até onde, outro paulista, Alexandre de Gusmão, antigo aluno de Belém da Cachoeira, acabaria traçando no mapa as fronteiras do Brasil. Para dar o movimento um sentido moral, sancionado pelo Direito e a Justiça, valeu algum tempo a presença em Piratininga de Dom Francisco de Souza, governador geral a princípio, depois da Repartição do Sul. Com idêntico fito, apontará mais tarde o genial Vieira o aproveitamento pela política da Metrópole dessa caudal de irreprimíveis energias, plano que afinal se realizou (75).

Dessa energia eram elementos componentes os tupis das aldeias de El-Rei. Como Deus escreve direito por linhas tortas, também êsses caminhos tortuosos, que conduziram alguns cabos de tropa da arrancada mameluca ao esmagamento das reduções - organizadas por jesuítas espanhóis, em território da Corôa de Espanha -, concorreram parcialmente para a criação dêste imenso espaço livre, onde, para glória de Deus e sob a inspiração das virtudes heróicas de Anchieta, nos. empenhamos hoje em construir esta pátria generosa e cristã. Anchieta nos inspire e nos proteja!

Sem pactuar, é claro, com os aludidos extravios, previsiveis em qualquer emprêsa humana, encarando apenas as estradas luminosas de um progresso conforme aos ditames da razão e da fé, vislumbrara o Taumaturgo e predisse a hodierna

(75). - H. A. Viotti, S. J., Vieira e os panlistas, Rev. Anchieta, Rio, I (1955), J. Lúcio de Azevedo, Cartas do Padre Antônịo Vieira, I, 135-137, 409, $415-16$. 
grandeza de São Paulo (76). Já agora a maior cidade do país, que, no seu prodigioso crescimento, avassalou há muito a velha Aldeia de Nossa Senhora dos Pinheiros, transformada hoje rum dos seus modernos bairros, a estadear, em tômo do Santuário de Nossa Senhora de Monserrate, a pujança de sua sociabilidade cristã, de sua operosidade vanguardeira; de suas realizações urbanísticas.

Pe. Hélo ABRANChes VIOTTI, S.J.

(76). - "E' finalmente a Vila de São Paulo digníssima de se verificar nela o célebre vaticínio do grande Padre José de Anchteta, que há ela de ser a metrópole do Brasil". Relatorio do Governador Antónlo Pais de Sande ao Conselho Ultramarino, janeiro de 1693. Anais da Bibl. Nac., XXXIX, 197-200. 